\title{
Screening of Bacterial and Fungal Biota Associated with Oreochromis niloticus in Lake Manzala and Its Impact on Human Health
}

\author{
Mahmoud M. M. Zaky, Mohsen E. Ibrahim \\ Department of Botany, Faculty of Science, University of Port Said, Port Said, Egypt \\ Email: Zakymahmoud67@gmail.com, mohsenhbrahim@yahoo.com
}

How to cite this paper: Zaky, M.M.M. and Ibrahim, M.E. (2017) Screening of Bacterial and Fungal Biota Associated with Oreochromis niloticus in Lake Manzala and Its Impact on Human Health. Health, 9, 697714.

https://doi.org/10.4236/health.2017.94050

Received: January 4, 2017

Accepted: April 27, 2017

Published: April 30, 2017

Copyright ( 92017 by authors and Scientific Research Publishing Inc. This work is licensed under the Creative Commons Attribution International License (CC BY 4.0).

http://creativecommons.org/licenses/by/4.0/

\begin{abstract}
In this study fish samples were investigated for Bacteria and Fungi, in fish parts, such as intestine, gills and skin. Bacterial counts of Total viable bacteria (T.V.B) reached more than $9.5 \times 10^{5} \mathrm{cfu}$ and faecal coliforms (F.C) reached 1.2 $\times 10^{5} \mathrm{cfu}$. Different species were identified, Using API technology. Escherichia coli comes first by being recording thirty number case of isolation constituting 36\%, it followed by Proteus mirabilis which is represented by twenty four number case of isolation accounting for 30\%. Other taxa viz: Klebsiella pneumonia, Citrobacter freundii, Providencia stuartii and Erwinia sp. came next according to their case number of isolation, they represented only by $7 \%$. They showed different antibiotics with different inhibitory concentrations, resistance pattern to gentamycin $10 \mu \mathrm{g}$, Penicillin G, tetracycline $30 \mu \mathrm{g}$, Ampicillin $10 \mu \mathrm{g}$, Ampicillin $30 \mu \mathrm{g}$, chloramphenicol (C) $30 \mu \mathrm{g}$, Rifampicin $25 \mu \mathrm{g}$, Streptomycin $5 \mu \mathrm{g}$, cefotaxime $15 \mu \mathrm{g}$. Mycological investigation revealed the presence of variety of fungal species, particularly, toxigenic species, such as, Aspergillus spp, Penicillium spp and Fusarium spp. These results are indication of the spoilage of fishes which caught from Lake Manzala and are risky for human consumption and hazardous to human health in this important area of Egypt, due to the high pollution condition of Lake Manzala.
\end{abstract}

\section{Keywords}

Indicator Bacteria, Pathogens, Tilapia spp, Mycotoxins, Fungi

\section{Introduction}

Fish and fish product are considered as preferable source of high nutritional values and highly desirable food due to its high quality animal protein content as its exceptional richness in calcium and phosphorus and its generous supply of $\mathcal{B}$ - 
complex vitamins. Fish provide a large percent of animal protein consumed by the world population. In tropical and subtropical countries, 60 percent of the people depend on fish for 40 percent or more of their protein [1]. Bacterial and fungal contamination of fish is considered the main cause of signs of spoilage as off flavor and unpalatable taste and it may constitute a public health hazard as well as many of economic losses [2] [3] [4]. At the time of harvest, fish carries a high microbial load on the surface of their skins, in their intestinal tracts and in their gills. The type and number of microorganisms that live in fish vary according to the season, the species and the natural habitat. Additional contamination may occur during the harvesting, handling or processing of the fish, also during the storage and transportation "Fish and Fishery Products Hazards and Controls Guidance, Fourth Edition-April 2011".

Nile tilapia (Oreochromis niloticus) is one of the most widely cultured fish in the world [5]. In Egypt, it ranks first as the most important wild and cultured fish [6]. It is considered the best growing species with desirable characteristics. It can be cultured successfully in Lake, ponds, cages, rice fields, impounding waters and integrated farming systems.

Manzala's lagoon is the largest brackish water body of the Nile Delta coastal lakes lies between $31^{\circ} 00^{\prime \prime}$ and $31^{\circ} 30^{\prime \prime}$ latitude and $31^{\circ} 45^{\prime \prime}$ and $32^{\circ} 20^{\prime \prime}$ longitude and is shallow with depth rarely exceeding one meter with a total area $\sim 700 \mathrm{~km}^{2}$ [7]. It occupies the north eastern corner of the Nile Delta between the Mediterranean Sea (North) and Suez Canal (East), while 5 Governorates share the western and southern Lake borders. The lake is supposed to have resulted from the accumulation of the Nile flood water, before the construction of the High Dam, in the low lying land which it occupies. It is the largest and most economically important of Egypt's coastal lakes where it provides an abundance of fish and an internationally important wintering area for water birds and staging area for migratory birds. It has been gradually transformed from a largely marine or estuarine environment to eutrophic brackish water system. The overall area of the lake was decline from more than $1400 \mathrm{~km}^{2}$ in the early 1970 s to less than 700 $\mathrm{km}^{2}$ in 2003 [8]. The Lake is considered an important and valuable natural resource ecosystem for fish catch, wildlife, hydrological and biological regime in Egypt. In the year 1979, the fish production was about 75,000 tons and the lake area was about 29,100 feddan (feddan $=0.42$ hectare). Many factors, such as pollution, and drying of the many parts of the lake, have reduced the fish production significantly, to about 47,500 tons in 1990 , when the lake area is19,000 feddan [9]. There are about 12,000 fisherman-representing families with a population about 50,000 people living on the islands of the lake [10].

The microbial biota of freshly fish is usually a reflection of the environment in which it was harvested. Generally, ponds and rivers that harbor fish may be the source of the microorganisms due to indiscriminate dumping of human and animal excreta as well as other environmental wastes into natural water bodies or washing of excreta from land into water during the rainy season [11]. Fish and other marine organisms that live in contaminated coastal water, poses a mi- 
crobial microbiota dependent on the existing in the waters where they live. In the mucus that covers the external surface of the fish, it has been identified bacteria of the genus: Pseudomonas, Salmonella, Micrococcus, Sarcina, Serratia and Vibrio. Regardless of the type of nourishment of the fish, which ingest bacteria on their food, it is registered a large number of these microorganisms in their digestive tract and epidermis, where also it has been identified species of genus Pseudomonas, Escherichia, Salmonella, Streptococcus, Staphylococcus, Clostridium and Vibrio [12].

Little attention has been given to the widespread occurrence of fungi, their presence and significance in aquatic environments [13] [14]. However [15] isolated 8 species of fungi from eggs and brood stock of rainbow trout $O$. mykiss. These isolates were Penicillium spp, Acreomonium spp, Alternaria spp, Fusarium solani, Aspergillus spp, Mucor spp, Saprolegnia spp. and Cladosporium spp.

Isolated microorganisms from feces or environmental waste contain antibiotic resistant gene that may disseminate and contaminate aquatic environment. Subsequently, fish contamination with antibiotic-resistant bacteria can be a major threat to public health, as it can be transferred to other bacteria of human clinical significance [16]. The choices of antibiotic for the treatment of common infectious diseases in humans are becoming increasingly limited, expensive and ineffective due to the emergence of antibiotic resistant bacteria [17].

The presence of diverse enteric bacteria (Citrobacter brackii, Citrobacter freundii, Enterobacter sakazakii, Enterobacter cloacae, Vibrio cholorae, Proteus mirabilis, Proteus vulgaris, Klebsiella pneumoniae and Aeromonas hydrophila) and mycotoxins producing fungi (Aspergillus spp., Fusarium spp., and Penicillium spp.,) in aquatic capture fish indicated the degree of habitat and handlers contamination. Their presence represents a potential hazard to humans, especially the immunocompromised consumers such as cases of HIV/AIDS.

This study was aimed to investigate the bacterial and mycobiota associated with apparently healthy as well as diseased fishes (Oreochromis niloticus) from Lake Manzala in Port Said governorate and to evaluate the hygienic health hazard of fish contaminated with some food borne pathogens.

\section{Materials \& Methods}

\subsection{Location and Site Description}

Lake Manzala is a brackish lake, sometimes called a lagoon, in north eastern Egypt on the Nile Delta near Port Said. It is the largest of the northern deltaic lakes of Egypt. As of 2008 it is $47 \mathrm{~km}$ long and $30 \mathrm{~km}$ wide (Figure 1).

Manzala Lagoon is a typical coastal lagoon ecosystem received two water types from two main sources [18]. Firstly, Mediterranean Seawater via three points, El-Gamil, El-Boughdady and New El-Gamil, which has been recently established [19] and secondly, fresh-highly enriched water from several drains and pumping stations. Simultaneously, saline-less productive seawater and fresh highly 


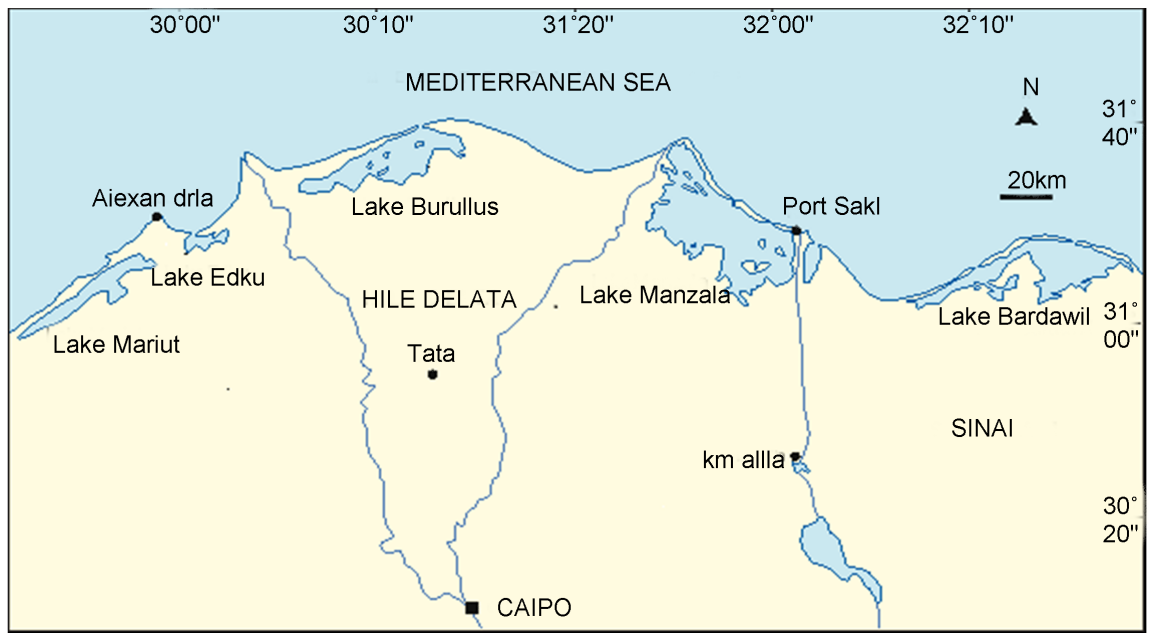

Figure 1. Lake Manzala.

nutrient loaded drainage water conductivity.

\subsection{Sampling Methodology}

20 Fresh fish samples were randomly selected and purchased from fishermen from Lake Manzala and immediately packed in sterile polyethylene bags and preserved on ice. All collected samples were transported and prepared for immediate bacteriological and fungal analysis. Fish tissues for microbiological analysis were the skin (outside fish surface), the gills (whole arches) and the entire gastrointestinal tract with spleen.

\subsection{Microbiological Analysis}

Quantitative bacteriological and fungal analysis of the fish samples were carried out using total plate count on nutrient agar (NA) while fungi isolation was carried out using Czapek's yeast extract agar (CYA) and potato dextrose agar (PDA). Total viable bacteria and faecal coli form were detected using MacConkey agar and Eosin Methylene Blue (EMB) agars respectively. Their counts were expressed in $\mathrm{cfu} / \mathrm{ml}$. The method of [20] was used.

Ten grams of flesh and gills of the fresh fish were collected using a dissecting set. These were separately added to $90 \mathrm{ml}$ of $0.1 \%$ peptone water and homogenized in a blender. $1 \mathrm{ml}$ of the homogenate was transferred to a test tube containing $9 \mathrm{ml}$ peptone water to obtain a dilution of $10^{-1}$. In a similar manner, $1 \mathrm{ml}$ was transferred from this dilution to a test tube containing $9 \mathrm{ml}$ diluents and the process was repeated until a dilution of $10^{-9}$ was obtained according to the method of [21].

\subsection{Characterization of the Isolates}

Bacterial isolates were characterized by standard microbiological methods including colonial (size, shape, colour, consistency, edges, elevation and opacity), morphological (Gram staining and arrangement/shape) and biochemical characterization (oxidase, indole, urease, citrate, catalase, sugar fermentation, me- 
thyl-red and Vorges-proskauer). Each isolate was subjected to a biochemical test using the Bergey's manual of systematic bacteriology according to [22] and the fungal isolates were identified according to the methods of [23]. Identification was confirmed by the recommended API 20E system (BioMerieux).

\subsection{Counts of Bacterial Isolates}

\subsubsection{Total Viable Count}

The plate count agar was inoculated with bacterial isolates and incubated at $37^{\circ} \mathrm{C}$ for $48 \mathrm{~h}$. After $48 \mathrm{~h}$, the colour, size, shape, texture surface elevation and margin of the colonies were observed with a microscope and recorded. The numbers of the colonies were counted, and the colony forming units per gram ( $\mathrm{cfu} / \mathrm{g})$ were calculated and recorded according to the methods of [24].

\subsubsection{Fecal Coliform}

The pour plate method was used to estimate the number of heterotrophic bacteria (plate count agar, $37^{\circ} \mathrm{C}, 48 \mathrm{~h}$ ), and the membrane filter technique was applied for Total coliforms (m-Endo medium, $37^{\circ} \mathrm{C}, 24 \mathrm{~h}$ ), Fecal coliforms (m-Fc agar, $44^{\circ} \mathrm{C}, 24 \mathrm{~h}$ ), and Enterococci (Slanetz and Bartley agar, $37^{\circ} \mathrm{C}, 48 \mathrm{~h}$ ) [25].

\subsection{Drug Resistant Bacteria}

Multi-drug resistant bacteria were isolated from fresh fish and fish handlers using conventional methods of bacterial isolation such as colonial morphology, gram staining and biochemical tests. The bacteria isolated include Escherichia coli, Proteus mirabilis, Klebsiella pneumonia, Citrobacter freundii, Providencia stuartii, Erwinia sp. These bacterial isolates were subjected to antibiotic susceptibility testing using disc diffusion technique against ten antimicrobial agents.

\subsection{Fish Fungal Isolation}

Dilution plate [26] technique was applied in order to get as good diversity as possible. Czapek's yeast extract agar (CYA) and potato dextrose agar (PDA) as isolation media and supplemented with Rose Bengal $(1 / 15,000)$ and chloramphenicol (50 ppm) for suppression of bacterial growth [27]. Ten grams of each fish part (skin \& muscle, gills, intestine) was homogenized in $100 \mathrm{ml}$ sterile water then diluted to $1 / 1000$. One milliliter of the diluted sample $\left(10^{-3}\right)$ was aseptically transferred into a sterile Petri dish then pour media. To obtain as much species as possible, six plates isolation medium were prepared from every fish part. After inoculating, plates were incubated at $27^{\circ} \mathrm{C}$ for 5 to 7 days, thereafter; developing colonies were identified and counted.

\subsection{Identification of Fungal Isolates}

Taxonomic identification of isolated fungi using phenotypic (macroscopic \& microscopic) approach down to the species level on standard morphology characteristics of fungal isolates down to the species level on standard media will mainly based on the following identification keys: [28] for Penicillium; [29] for 
Aspergillus, [30] [31] for dematiaceous hyphomycetes, and more dematiaceous hyphomycetes; [32] for Fusarium; [33] for miscellaneous fungi; and [34] for ascomycetes.

\section{Results}

Indeed fish and other free-swimming marine animals do not usually carry those organisms generally considered to be typical of the mammalian microflora, including Escherichia coli, the "faecal coliforms", and enterococci. The presence of human enteric organisms on marine food products is clear evidence of contamination from a terrigenous source.

\subsection{Bacterial Counts}

\subsubsection{Total Viable Count}

As for the bacterial counts of Oreochromis niloticus, data of Table 1 shows that counts varied from one fish part to another. While intestine showed a mean count of $3.1 \times 10^{5}$; gills revealed a mean count of $6.2 \times 10^{4}$. Still third fish part skin which obtains a mean count of $2.9 \times 10^{3}$.

\subsubsection{Fecal Coli Forms Count}

Fish samples (skin, gill and intestine) of tilapia have been surveyed for their fecal coli form population densities (Table 2).

The data shows that count differ markedly in different fish parts. Intestine showed a mean count of $2.9 \times 10^{4}$; gill obtains a mean count of $5 \times 10^{3}$; where skin revealed a mean count of $0.5 \times 10^{3}$.

During the fish bacterial investigation, a total number of six species has been reported from the three fish parts (skin, gill, intestine). Recorded bacteria belong to six genera Table 3; of which Escherichia coli comes first by being recording thirty number case of isolation constituting $36 \%$, it followed by Proteus mirabilis which is represented by twenty four number case of isolation accounting for

Table 1. Count and mean count of total viable bacteria of Tilapia fish.

\begin{tabular}{cccc}
\hline \multirow{2}{*}{ Parameter } & \multicolumn{3}{c}{ Total viable bacteria } \\
\cline { 2 - 4 } Organ & Minimum & Maximum & Mean \\
\hline Intestine & $1 \times 10^{5}$ & $9.5 \times \times 10^{5}$ & $3.1 \times 10^{5} \pm 2.9 \times 10^{5}$ \\
Gills & $1.8 \times 10^{4}$ & $1.2 \times 10^{5}$ & $6.2 \times 10^{4} \pm 3.8 \times 10^{4}$ \\
Fish skin & $1.5 \times 10^{3}$ & $1.4 \times 10^{5}$ & $2.9 \times 10^{3} \pm 3.5 \times 10^{3}$ \\
\hline
\end{tabular}

Table 2. Count and mean count of fecal coli form of Tilapia fish.

\begin{tabular}{cccc}
\hline \multirow{2}{*}{ Parameter } & \multicolumn{3}{c}{ Fecal coli form } \\
\cline { 2 - 4 } Organ & Minimum & Maximum & Mean \\
\hline Intestine & $5 \times 10^{2}$ & $1.2 \times 10^{5}$ & $2.9 \times 10^{4} \pm 3.1 \times 10^{4}$ \\
Gills & $1 \times 10^{2}$ & $2.5 \times 10^{4}$ & $5 \times 10^{3} \pm 6 \times 10^{3}$ \\
Fish skin & 50 & $3.3 \times 10^{3}$ & $0.5 \times 10^{3} \pm 0.1 \times 10^{3}$ \\
\hline
\end{tabular}


Table 3. Number and percentage of bacterial species isolated from Oreochromis niloticus.

\begin{tabular}{ccc}
\hline Species & Rate number of isolation & Percentage \\
\hline Escherichia coli & 30 & $36 \%$ \\
Proteus mirabilis & 24 & $30 \%$ \\
Klebsiella pneumonia & 6 & $7 \%$ \\
Citrobacter freundii & 6 & $7 \%$ \\
Providencia stuartii & 6 & $7 \%$ \\
Erwinia sp. & 6 & $7 \%$ \\
\hline
\end{tabular}

30\%. Other taxa viz: Klebsiella pneumonia, Citrobacter freundii, Providencia stuartii and Erwinia sp. came next according to their case number of isolation, they represented only by $7 \%$.

\subsection{Antibiotic Susceptibility Testing}

Isolates were selected for antimicrobial susceptibility testing according to Kirby-Bauer disc diffusion techniques on Mueller Hinton agar using the following antibiotic discs (Oxoid): gentamycin $10 \mu \mathrm{g}$, Penicillin G, tetracycline $30 \mu \mathrm{g}$, Ampicillin $10 \mu \mathrm{g}$, chloramphenicol (C) $30 \mu \mathrm{g}$, Rifampicin $25 \mu \mathrm{g}$, Streptomycin $5 \mu \mathrm{g}$, cefotaxime $15 \mu \mathrm{g}$. The zone of inhibition was interpreted according to Clinical Laboratory Standard Institute [35]. Multidrug resistance was defined as resistance to $\geq 4$ antimicrobials [36].

Data of Table 4 revealed that while some tested species resistant to most antibiotics, these include: Escherichia coli, Proteus mirabilis, Klebsiella pneumonia and Providencia stuartii; others susceptible e. g. Citrobacter freundii, Erwinia sp.

\subsection{Fungal Counts}

The distribution pattern of mycobiota based on the presence/absence in fish part (skin, gill, intestine) under investigation showed that recorded taxa could be temporarily classified into three groups (Table 5).

Group 1, comprises taxa of occurrence restricted to one part only (8 species) e,g. Acremonium sp, Aspergillus versicolor, Fusarium solani.

Group 2, consists of species occurring in two fish parts (6 species) e.g. Alternaria alternarta, Aspergillus flavus, Fusarium oxysporum and Trichoderma sp.

Group 3, contains species of common occurrence to almost all fish parts (3 species) e.g. Aspergillus niger, Aspergillus terreus, Cladosporium cladosporioides and Penicillium cyclopium.

Data of Table 5 and Figure 2 also revealed that, the prevailing genus is $A s$ pergillus by showing a spectrum of four species; Penicillium comes next by revealing three species. The remaining taxa were represented only by two or one species.

In view of spectrum of species the range of species varied among fish parts. The richness of species in intestine showed the highest spectrum by obtaining 


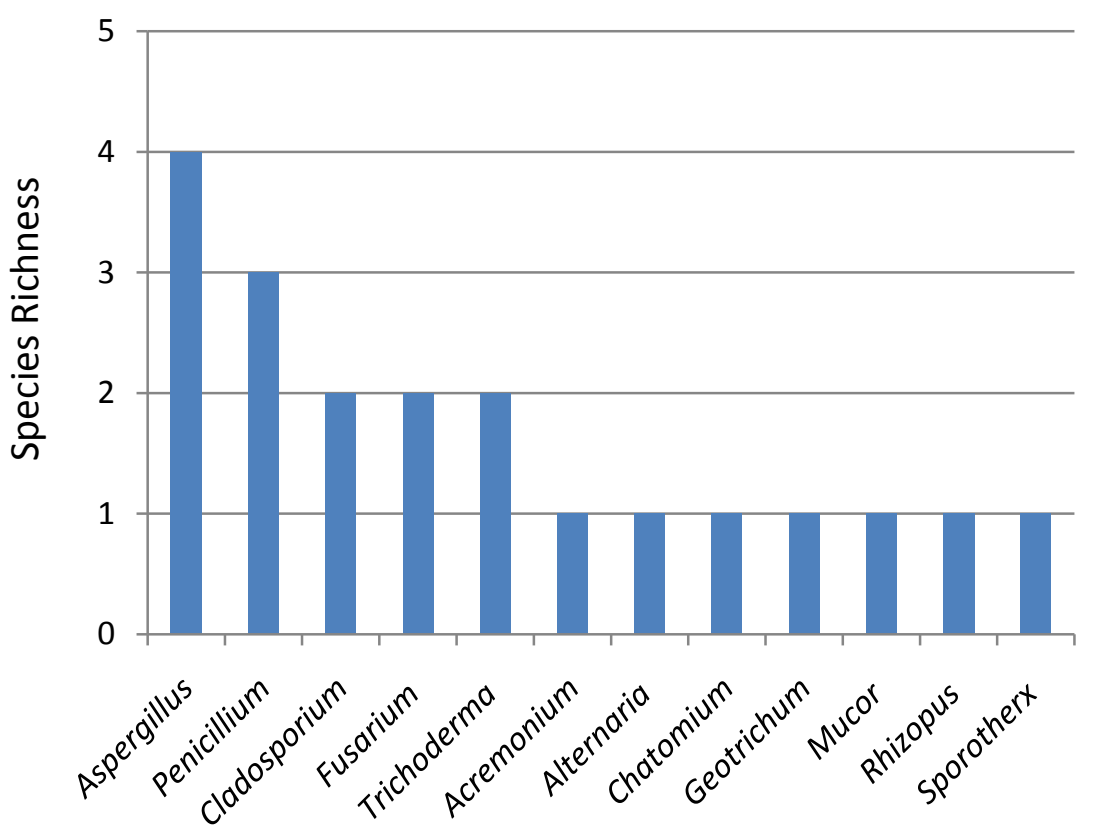

Figure 2. Species Richness of Isolated Genera.

Table 4. Antibiotic susceptibility testing.

\begin{tabular}{|c|c|c|c|c|c|c|c|c|}
\hline Species & 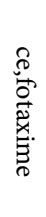 & 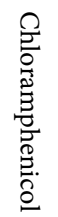 & 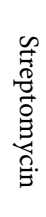 & 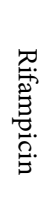 & $\begin{array}{l}\text { 总 } \\
\text { 总. } \\
\text { 它 }\end{array}$ & 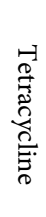 & 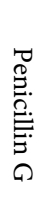 & 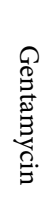 \\
\hline Escherichia coli & $\mathrm{R}^{*}$ & $\mathrm{R}$ & $\mathrm{R}$ & $\mathrm{R}$ & $\mathrm{R}$ & $S^{*}$ & $\mathrm{R}$ & $S$ \\
\hline Proteus mirabilis & $\mathrm{R}$ & $\mathrm{R}$ & S & $\mathrm{R}$ & $\mathrm{R}$ & S & $\mathrm{R}$ & $S$ \\
\hline Klebsiella pneumonia & S & $\mathrm{R}$ & $\mathrm{R}$ & $\mathrm{R}$ & $\mathrm{R}$ & S & $\mathrm{R}$ & $S$ \\
\hline Citrobacter freundii & S & $\mathrm{R}$ & $S$ & $\mathrm{R}$ & $\mathrm{R}$ & $S$ & $\mathrm{R}$ & $S$ \\
\hline Providencia stuartii & $\mathrm{R}$ & $\mathrm{R}$ & $\mathrm{R}$ & $\mathrm{R}$ & $\mathrm{R}$ & $\mathrm{R}$ & $S$ & $\mathrm{R}$ \\
\hline Erwinia sp. & $\mathrm{R}$ & S & $\mathrm{R}$ & $\mathrm{S}$ & $\mathrm{R}$ & S & $\mathrm{R}$ & $S$ \\
\hline
\end{tabular}

$\mathrm{R}^{*}=$ resistant, $\mathrm{S}^{*}=$ susceptible.

15 species; followed by gill by accommodating 11 species. Skin came last one by being revealed only 9 species (Figure 3 ).

It's worthy to mention here that during this investigation we noticed that $A s$ pergillus terreus induce disease in the tilapia and this considers a new record in Egypt (Figure 4). However this, from human health point of view, is very important because $A$. terreus produce mycotoxins.

\section{Discussion}

Fish is considered one of the most important sources of human dietary animal protein worldwide, especially in Egypt as well as other African countries [37]. Lake Manzala is exposed to many pollutants including untreated sewage, agricultural and industrial wastes which compromise the health state of the fisher 
Table 5. Fungal biota isolated from fish parts.

\begin{tabular}{|c|c|c|c|}
\hline \multirow{2}{*}{$\begin{array}{l}\text { Fish part } \\
\text { Fungal species }\end{array}$} & \multicolumn{3}{|c|}{ presence/absence } \\
\hline & Skin & Gills & Intestine \\
\hline Acremonium $s p$ & ---- & ---- & + \\
\hline Alternaria alternarta & + & + & ---- \\
\hline Aspergillus flavus & + & ---- & + \\
\hline Aspergillus niger & + & + & + \\
\hline Aspergillus terreus & + & + & + \\
\hline Aspergillus versicolor & ---- & ---- & + \\
\hline Chatomium globosum & ---- & + & ---- \\
\hline Cladosporium cladosporioides & + & + & + \\
\hline Cladosporium $s p$ & --- & + & + \\
\hline Fusarium oxysporum & + & ---- & + \\
\hline Fusarium solani & + & ---- & ---- \\
\hline Geotrichum candidum & --- & + & ---- \\
\hline Mucor hiemalis & ---- & ---- & + \\
\hline Penicillium chrysogenum & ---- & + & --- \\
\hline Penicillium citrinum & --- & + & + \\
\hline Penicillium cyclopium & + & + & + \\
\hline Rhizopus stolonifer & + & ---- & + \\
\hline Sporotherx $s p$ & ---- & + & + \\
\hline Trichoderma koningii & ---- & ---- & + \\
\hline Trichoderma $s p$ & + & --- & + \\
\hline
\end{tabular}

men and the population inhabiting the contaminated areas. Fish samples of Lake Manzala were found to have very high contents of bacterial pathogens as well as contaminant with different mycotoxin producing fungal species. Microorganisms from human origin such as E. coli, S. aureus and Klebsiella have been found to survive and multiply in the gut and tissues of fish which render fish a potential source of human disease over long periods [38].

In this study different type of bacteria of human importance were isolated from tested fish (Oreochromis niloticus) catches from Lake Manzala. Our data revealed that recorded bacteria belong to six genera of which Escherichia coli comes first by being recording thirty number case of isolation constituting $36 \%$, it followed by Proteus mirabilis which is represented by twenty four number case of isolation accounting for $30 \%$. Other taxa viz: Klebsiella pneumonia, $\mathrm{Ci}$ trobacter freundii, Providencia stuartii. Most fish related food borne illnesses are regarded to Enterobacteriaceae family.

Our results are in corresponding with: [39] found when analyzing fish; all the fish samples were contaminated on surface and internally with very high amounts of pathogenic bacteria. This confirms that Lake Manzala fish (tilapia) is 


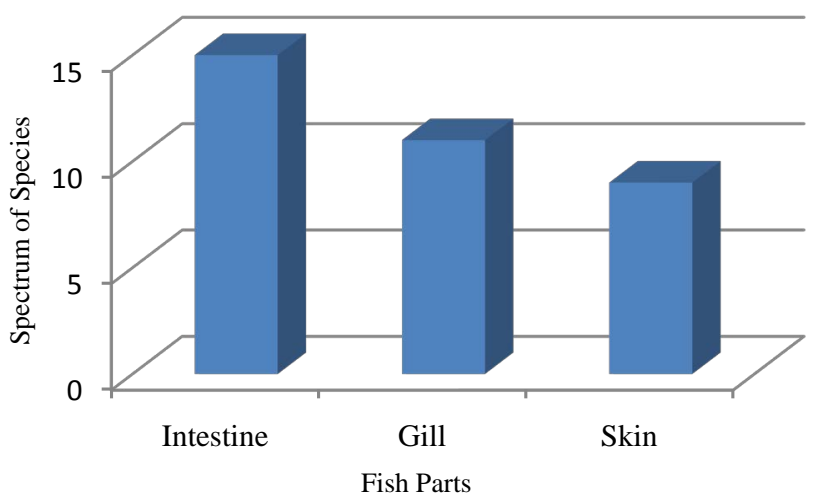

Figure 3. Spectrum of fungal species isolated from fish parts.

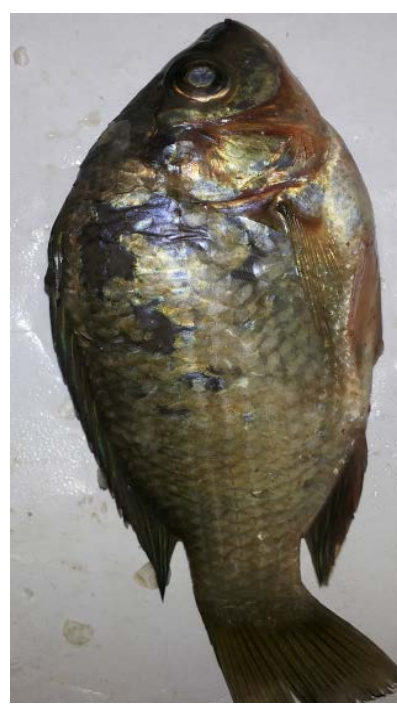

(a)

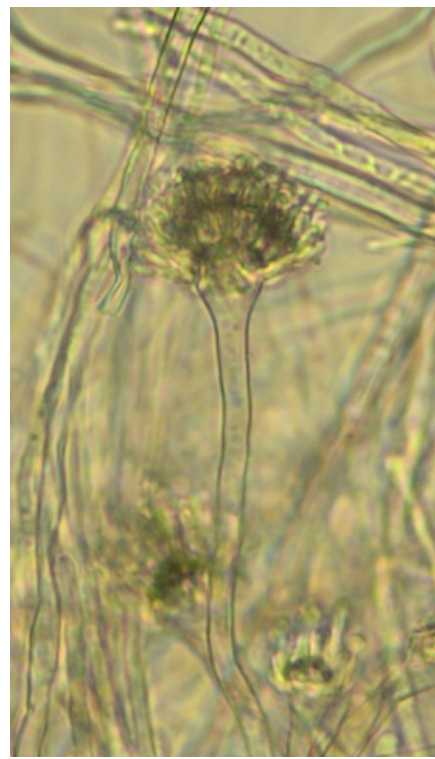

(c)

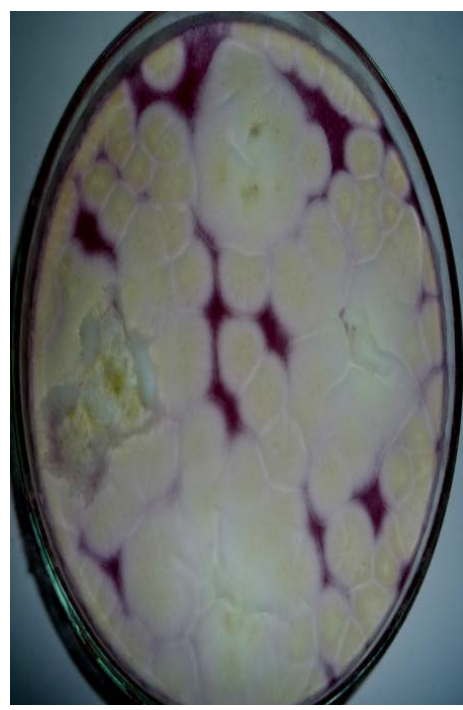

(b)

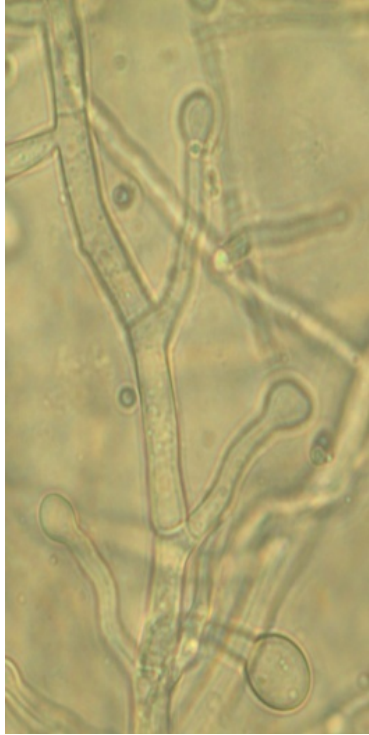

(d)

Figure 4. (a) Fish surface showing lesions in the skin; (b) Plate showing colony morphology of Aspergillus terreus, (c) Micromorphology conidiophore \& head (magnification 400×); (d) Blastoconidia (magnification 400×). 
highly polluted and dangerous for human health. [40] found Enterobacteriaceae $\left(3.5 \times 10^{5} \mathrm{cfu} / \mathrm{g}\right)$ in crayfish from the Nile River. [41] [42] also found that bacteria belonging to Enterobacteriaceae family were the predominant isolates in the fish samples. [43] found that microbial quality of the tilapia indicated that all tissue samples except muscle tissues were contaminated with fecal coliforms where Escherichia coli is the most common contaminant and is often encountered in high numbers. [44] found that total coliforms count range in fish was between $3.0 \times 10^{3}-7.5 \times 10^{6}$. [45] in his study isolated of Enterobacteriacaea as $55 \%$ from collected samples indicated public health hazards and concern, particularly isolation of some highly pathogenic agents such as Salmonella spp., Shigella spp., as well as the pathogenic E. coli., and potential pathogenic organisms such as Klebsiella spp., Citrobacter spp., and Proteus spp. [46] reported that isolation of some most pathogenic organisms such as Salmonella spp., E. coli and potential pathogenic organisms as Klebsiella spp., Citrobacter spp. and Proteus spp., from fish and fish products gives an indication about environmental fecal pollution of fish. [47] notified that the presence of coliforms above the acceptable limit in fish offered a risk to the consumers. This is because coliforms grow rapidly at ambient temperatures and spoil the fish in a short period of time.

Our results are also in consistent with data obtained by: [48] they revealed a moderate level of bacterial contamination of fish sold in supermarkets and by street vendors. The results obtained by [14] indicate that these rivers may be potential pathways for human and other animal contamination with Salmonella spp., filamentous fungi, and yeasts, which contribute to the pollution of marine waters and the surrounding environment. [49] Who found bacteria belonging to the Enterobacteriaceae family as predominant in whole gutted and filleted sea bass. The emerging pathogen, Enterobacter sakazaki, causes a lot of food borne outbreaks in children, elderly and immuno-compromised patients. The presence of these opportunistic and pathogenic members of bacteria in fish represents a threat to vulnerable groups in society [50].

Occurrence of E. coli, Klebsiella, Proteus and Brucella in fish may result from indiscriminate deposition of human and animal excreta as well as other environmental wastes into ponds and rivers that harbor fish or through washing of land surfaces into water bodies during the rainy season [11]. Free roaming animals especially dogs and birds contribute to fecal contamination of surface water and ponds [51] [52]. These microorganisms in water may carry gene of multi drug resistance that are transferable between human, animals and the environment [53].

Fungal analysis of tested tilapia fish samples based on dilution-plating technique using Czapek's-yeast extract agar media revealed that 12 genera belonging to 20 fungal species were identified (Table 5). The genera of highest occurrence were Aspergillus (4 species) and Penicillium (3 species) respectively. A. niger, $A$. terreus A. flavus, $P$. cyclopium were the most common species. The remaining fungal genera and species were less frequent. Most of the recorded fungal species in this study had identified before from fresh water fish [54] [55]. However, our 
findings are in agreement with results obtained in Egypt and other countries all over the world: [15] reported the occurrence of different fungal species of genera including, Penicillium, Acremonium, Alternaria, Fusarium, Aspergillus, Mucor, Saprolegnia and Cladosporium from the eggs and brood stock of rainbow trout. [56] can be able to isolate Paeciliomyces spp., Aspergillus spp., Penicillium sp., and Trichoderma sp. from Nile tilapia, Tilapia zilli. [57] Isolated moulds belonged to the following genera: Saprolegnia, Aspergillus, Fusarium, Mucor, Penicillium, Rhizopus, Scopulariopsis, Paeciliomyces and Curvularia as normal mycobiota and these species may be regarded as opportunistic pathogens. [58] isolated 7 fungal species from stockfish in Nigeria and these included $A$. flavus, A. fumigatus, A. niger, Trichophyton verrucosum, Rhizopus sp Penicillium spp. and Mucor sp. [59] isolated Penicillium expansum, Penicillium citrinium; Aspergillus terreus, Aspergillus sp; Alternaria spp. and 11 other fungal species from infected eggs of rainbow trout. [60] isolated five different species of fungi including Fusarium, Aspergillus, Rhizopus, Mucor, and Penicillium from 8 edible smoke-dried freshwater fishes. [61] reported that aspergillomycosis has been principally described in African fish, especially the tilapia Oreochromis sp. A number of Aspergillus species such as A. flavus, A. japonicus, and A. terreus are involved in this infection.

Our results however, are also in compatible with outcomes of many investigations in Egypt and elsewhere: [62]-[75].

Pollution of fish with mycotoxin produced by fungi such as Aspergillus, Fusarium, and Penicillium likely lead to accumulation of these toxins in fish tissues. The risk for mycotoxins contamination may occur as a result of nourishment by the contaminant fish tissues in considerable quantities. Aflatoxins, Ochratoxin A and sterigmatocystin are thermostable and have an ability to accumulate in the organism [76]. Subsequently processing of fish does not remove or reduce the presence of mycotoxins in fish tissues. However, there are a lot studies in which the pollution with mycotoxin mainly Aspergillus has been treat e.g. [77] [78].

Multi drug resistance to strains is defined as being resistant to four or more antimicrobial agents [35] but sometimes as low as two antibiotics from different classes [79]. The result of this study revealed the presence of multidrug resistant bacteria from Oreochromis niloticus fishes. Some isolates showed high resistance to almost all tested antibiotics viz: Providencia stuartii and E. coli. Some exhibited resistance like Proteus mirabilis \& Klebsiella pneumonia. Still other displayed moderate resistance the results of this study agree with the obtained data by many investigators: [80]-[85].

Presence of $E$. coli in food indicates the possible cause of many gastro-intestinal diseases [86] and may constitute potential danger of antibiotic resistance transfer from aquatic bacteria to human.

\section{Conclusions}

The presence of diverse enteric bacteria in fish indicates the contamination from Lake Manzala and handlers, representing a potential hazard to human health 
especially those who are sick or are on immunosuppressive drugs. Stringent regulations and monitoring activities coupled with food safety training of suppliers (fishermen and traders) and consumers on various aspects of good hygiene practice and good manufacturing practice is much recommended. The findings in this study emphasize the importance of studying multiple genera of bacteria from fishes as sources of human exposure to antibiotic resistance strains. Therefore presence of multiple bacteria from fish and fish handlers poses not only risk of disease to the fishes but public health hazard to fish handlers and consumers in general.

The diversity and density of fungi may be, in fact, valid indicators of Lake Pollution and whether they represent a health hazard to the users of these waters are questions to be addressed by further microbiological investigation and epidemiological surveys. However, an action plan to protect this Lake and the surrounding environment from sewage and industrial effluents should be devised.

\section{References}

[1] WRI (World Resources Institute) (1994) World Resources 1994-5. Oxford University Press, New York, 400.

[2] Håstein, T., Hjeltnes, B., Lillehaug, A., Utne Skåre, J., Berntssen, M. and Lundebye, A.K. (2006) Food Safety Hazards That Occur during the Production Stage: Challenges for Fish Farming and the Fishing Industry. Revue Scientifique et Technique, 25, 607-625.

[3] Hassan, A.H.M., Noor-El Deen, A.E., Galal, H.M., Sohad, M., Dorgham, M.A., Bakry, M.A. and Hakim, A.S. (2012) Further Characterization of Enterobacteriaceae Isolated from Cultured Freshwater Fish in Kafr El Shiek Governorate: Clinical, Biochemical and Histopathological Study with Emphasis on Treatment Trials. Global Veterinaria, 9, 617-629.

[4] Zaky, M.M.M. and Salem, M.A.M. (2015) Environmental Factors Influencing Antibiotic Resistant Bacterial Pathogens in Polluted Lake Manzala, Egypt. Journal of Bacteriology \& Parasitology, 6, Article ID: 1000249.

[5] Trewavas, E. (1983) Tilapine Fishes of the Genera Sarotherodon, Oreochromis and Danakilia. Cornell University Press, Ithaca, NY. https://doi.org/10.5962/bhl.title.123198

[6] Mur, R. (2014) Development of the Aquaculture Value Chain in Egypt. Report of the National Innovation Platform Workshop, Cairo, 19-20 February 2014.

[7] Tahoun, S.A. (2007) Environmental Perspectives of the Port Said Area. Final Report of Plan of Action for an Integrated Coastal Zone Management in the Area of Port Said (Egypt), 230.

[8] Ahmed, M., El Leithy, B., Thompson, J., Flower, R., Ramdani, M., Ayache, F. and Hassan, S. (2009) Application of Remote Sensing to Site Characterization and Environmental Change Analysis of North Africa Coastal Lagoons. Hydrobiologia, 622, 147-171. https://doi.org/10.1007/s10750-008-9682-8

[9] Rabeh, S.A., Sabae, S.Z. and Abou El-Gheit, E.N. (2013) Microbiological Water Quality and Bacterial Infections among Tilapia Fish of Lake Manzala, Egypt. International Journal of Environment \& Water, 2, 75-85.

[10] Zaky, M.M., Salem, M., Persson, K.M. and Eslamian, S. (2011) Incidence of Aeromonas Species Isolated from Water and Fish Sources from Lake Manzala in Egypt. 
International Journal of Hydrology Science and Technology, 1, 47-62. https://doi.org/10.1504/IJHST.2011.040740

[11] Cabral, P.S. (2010) Water Microbiology. Bacterial Pathogens and Water. International Journal of Environmental Research and Public Health, 7, 3658-3703. https://doi.org/10.3390/ijerph7103657

[12] Alam, M., Hasan, N.A., Sadique, A., Bhuiyan, N.A., Ahmed, K.U., Nusrin, S., Nair, G.B., Siddique, A.K., Sack, R.B., Sack, D.A., Huq, A. and Colwell, R.R. (2006) Seasonal Cholera Caused by Vibrio cholerae Serogroups O1 and O139 in the Coastal Aquatic Environment of Bangladesh. Applied Environmental Microbiology, 72, 4096-4104. https://doi.org/10.1128/AEM.00066-06

[13] Pitlik, S., Berger, S.A. and Huminer, D. (1987) Nonenteric Infections Acquired through Contact with Water. Reviews of Infectious Diseases, 9, 54-63.

https://doi.org/10.1093/clinids/9.1.54

[14] Arvanitidou, M., Kanellou, K. and Vagiona, D.G. (2005) Diversity of Salmonella spp. and Fungi in Northern Greek Rivers and Their Correlation to Fecal Pollution Indicators. Environmental Research, 99, 278-284.

https://doi.org/10.1016/j.envres.2005.01.002

[15] Fadaeifard, F.F., Raissy, M., Bahrami, H., Rahimi, E. and Najafipoor, A. (2011) Freshwater Fungi Isolated from Eggs and Broodstocks with an Emphasis on Saprolegnia in Rainbow Trout Farms in West Iran. African Journal of Microbiology Research, 4, 3647-3651.

[16] O’Brien, T.F. (2002) Emergence, Spread and Environmental Effect of Antimicrobial Resistance: How Use of an Antimicrobial Anywhere Can Increase Resistance to Any Antimicrobial Anywhere Else. Clinical Infectious Diseases, 34, S78-S84. https://doi.org/10.1086/340244

[17] Weese, J.S., Blondeau, J.M., Boothe, D., Breitschwerdt, E.B., Guardabassi, L., Hillier, A., Lloyd, D.H., Papich, M.G., Rankin, S.C., Turnidge, J.D. and Sykes, J.E. (2011) Antimicrobial Use Guidelines for Treatment of Urinary Tract Disease in Dogs and Cats: Antimicrobial Guidelines Working Group of the International Society for Companion Animal Infectious Diseases. Veterinary Medicine International, 2011, Article ID: 263768.

[18] Maclaren, J.F., Stevenson, M. and Kellogg, R. (1980) Lake Manzala Study. Aquaculture Site Selection Report, Ministry of Development and New Communities and United Nations Development Programme, Office of Projects Execution.

[19] Fayed, D.B. (2004) Aspects of Manzalah Lake Pollution on Mugil Species. M.Sc. Thesis, Girls' College, Ain Shams University, Cairo.

[20] Fawole, M.O. and Oso, B.A. (2001) Laboratory Manual of Microbiology. Revised Edition, Spectrum Books, Ibadan.

[21] Esther, A., Oramadike, C.E., Abraham-Olukayode, A.O. and Adejonwo, O.A. (2010) Bacteriological Quality of Street Vended Smoked Blue Whiting (Micromesistus poutasou). International Journal of Food Safety, 12, 122-126.

[22] Bergey, D.H. and Holt, J.G. (1994) Bergey's Manual of Determinative Bacteriology. 9th Edition, Williams \& Wilkins, Baltimore, Maryland.

[23] Treagan, L. and Pulliam, L. (1982) Medical Microbiology Procedures. W. B. Saunders Company, Toronto, Canada, 234-236.

[24] Ólafsdóttir, G., Martinsdóttir, E., Oehlenschläger, J., Dalgaard, P., Jensen, B., Undeland, I., Mackie, I.M., Henehan, G., Nielsen, J. and Nielsen, H. (1997) Methods to Evaluate Fish Freshness in Research and Industry. Trends in Food Science and Technology, 8, 258-265. https://doi.org/10.1016/S0924-2244(97)01049-2 
[25] American Public Health Association (APHA) (1995) Standard Methods for the Examination for Water and Wastewater. 19th Edition, Byrd Prepess Springfield, Washington DC.

[26] Garrett, S.D. (1981) Soil Fungi and Soil Fertility. 2nd Edition, The Macmillan Company, Oxford, New York.

[27] Smith, N.R. and Dawson, V.T. (1944) The Bacteriostatic Action of Rose Bengal in Media Used for the Plate Counts of Soil Fungi. Soil Science, 58, 467-471.

[28] Pitt, J.I. (1980) The Genus Penicillium and Its Teleomorphic States Eupenicillium and Talaromyces. Academic Press, London, $634 \mathrm{p}$.

[29] Raper, K.B. and Fennell, D.I. (1965) The Genus Aspergillus. Williams \& Wilkins, Baltimore.

[30] Ellis, M.B. (1971) Dematiaceous Hyphomycetes. Commonwealth Mycological Institute, Kew, Surrey, England, 608.

[31] Ellis, M.B. (1976) More dematiaceous hyphomycetes. Commonwealth Mycological Institute, Kew, Surrey, England, 507.

[32] Booth, C. (1971) Fusarium, Laboratory Guide to the Identification of the Major Species. Commonwealth Mycological Institute, Kew, Surrey, England.

[33] Domsch, K.H., Gams, W. and Anderson, T.H. (2007) Compendium of Soil Fungi. IHW-Verl, Eching, 672 p.

[34] Guarro, J., Gene, J., Stchigel, A.M. and Figueras, M.J. (2012) Atlas of Soil Ascomycetes. Issue 10 of CBS Biodiversity Series, Holland.

[35] CLSI, Ed. (2010) Clinical and Laboratory Standards Institute. Performance Standards for Antimicrobial Susceptibility Testing: Twentieth Informational Supplement M100-S20. CLSI, Wayne, PA, USA.

[36] Oteo, J.E., Lazaro, F.J., de Abajo, F.B. and Campos, J. (2005) Antimicrobial-Resistant Invasive Escherichia coli, Spain. Emerging Infectious Diseases, 11, 546-553. https://doi.org/10.3201/eid1104.040699

[37] Kumolu-Johnson, C.A. and Ndimele, P.E. (2011) A Review on Post-Harvest Losses in Artisanal Fisheries of Some African Countries. Journal of Fisheries and Aquatic Science, 6, 365-378. https://doi.org/10.3923/jfas.2011.365.378

[38] Udeze, A.O., Talatu, M., Ezediokpu, M.N., Nmwanze, J.C., Onoh, C. and Ononko, I.O. (2012) The Effect of Klebsiella pneumoniae on Catfish (Clarias gariepinus). Researcher, 4, 51-59.

[39] Saleh, A., Shawky, R., Sabae, Z. and Abou El-Gheit, E.N. (2013) Microbiological Water Quality and Bacterial Infections among Tilapia Fish of Lake Manzala, Egypt. International Journal of Environment \& Water, 2, 75-85.

[40] Elmossalami, M.K. (1997) Safety and Quality of Freshwater Crayfish (Procambarus clarkia)in the Nile River. Journal of Tropical Microbiology, 43, 126-128.

[41] Gonzalez-Rodriguez, M.N., Sanz, J.J., Santos, J.A., Otero, A. and Garcia-Lopez, M.I. (2002) Numbers and Types of Microorganisms in Vacuum-Packed Cold-Smoked Freshwater Fish at the Retail Level. International Journal of Food Microbiology, 77, 161-168. https://doi.org/10.1016/S0168-1605(02)00048-X

[42] Tsai, Y.H., Kung, H.F., Lee, T.M., Lin, G.T. and Hwang, D.F. (2004) Histamine Related Hygienic Qualities and Bacteria Found in Popular Commercial Scombroid Fish Fillets in Taiwan. Journal of Food Protection, 67, 407-412. https://doi.org/10.4315/0362-028X-67.2.407

[43] Thampuran, N., Surendraraj, A. and Surendran, P.K. (2005) Prevalence and Characterization of Typical and Atypical Escherichia coli from Fish Sold at Retail in 
Cochin, India. Journal of Food Protection, 68, 2208-2211.

https://doi.org/10.4315/0362-028X-68.10.2208

[44] Arannilewa, S.T., Salawu, S.O., Sorungbe, A.A. and Ola-Salawu, B.B. (2006) Effect of Frozen Period on the Chemical, Microbiological and Sensory Quality of Frozen Tilapia fish (Sarotherodun galiaenus). Nutrition and Health, 18, 185-192. https://doi.org/10.1177/026010600601800210

[45] Yagoub, S.O. (2009) Isolation of Enterobacteriaceae and Pseudomonas spp. from Raw Fish Sold in Fish Market in Khartoum State. Journal of Bacteriology Research, 1, 85-88.

[46] Wogu, M.D. and Maduakol, M. (2010) Evaluation of Microbial Spoilage of Some Aqua Cultured Fresh Fish in Benin City Nigeria. Ethiopian Journal of Environmental Studies and Management, 3, 18-22.

[47] Geldreich, E.E. and Clarke, N.A. (1966) Bacterial Pollution Indicators in the Intestinal Tract of Freshwater Fish. Applied Environmental Microbiology, 14, 429-437.

[48] Mhango, M., Mpuchane, S.F. and Gashe, B.A. (2010) Incidence of Indicator Organisms, Opportunistic and Pathogenic Bacteria in Fish. African Journal of Food Agriculture Nutrition and Development, 10, 4202-4218.

https://doi.org/10.4314/ajfand.v10i10.62898

[49] Paleologos, E.K., Savvaidis, I.N. and Komtominas, M.G. (2004) Biogenic Amine Formation and Its Relation to Microbiological Sensory Attributes in Ice-Stored Whole Gutted and Filleted Mediterranean Sea Bass (Dicentrarchus labrax). International Journal of Food Microbiology, 21, 549-557.

https://doi.org/10.1016/j.fm.2003.11.009

[50] Institute of Food Technologists (2004) Bacteria Associated with Foodborne Diseases. 1-25.

[51] Green, H.C., Dick, L.K., Gilpin, B., Samadpour, M. and Field, K.G. (2012) Genetic Markers for Rapid PCR Based Identification of Gull, Canada Goose, Duck and Chicken Fecal Contamination in Water. Applied and Environmental Microbiology, 78, 503-510. https://doi.org/10.1128/AEM.05734-11

[52] Mauffret, A., Caprais, M. and Gourmelon, M. (2012) Relevance of Bacteroidales and F-Specific RNA Bacteriophages for Efficient Fecal Contamination Tracking at the Level of a Catchment in France. Applied and Environmental Microbiology, 78, 5143-5152. https://doi.org/10.1128/AEM.00315-12

[53] Da Costa, P.M., Loureiro, L., Augusto, J. and Matos, F. (2013) Transfer of Multidrug-Resistant Bacteria between Intermingled Ecological Niches: The Interface between Humans, Animals and the Environment. International Journal of Environmental Research and Public Health, 10, 278-294.

https://doi.org/10.3390/ijerph10010278

[54] El-Sayed, Y.S.A. (1995) Mycological Studies on Locally Produced Smoked Fish with Special Reference to Toxigenic Strains. PhD Thesis, Zagazig University, Egypt.

[55] Edris, A.M. (1996) Microbial Evaluation of Some Marketed Smoked Fish. Zagazig Zagazig Veterinary Journal, 24, 76-81.

[56] Hashem, M. (2011) Isolation of Mycotoxin-Producing Fungi from Fishes Growing in Aquacultures. Research Journal of Microbiology, 6, 862-872. https://doi.org/10.3923/jm.2011.862.872

[57] Refai, M.K., Laila, A.M., Amany, K.M. and Shimaa, El-S.M.A. (2010) The Assessment of Mycotic Settlement of Freshwater Fishes in Egypt. Journal of American Science, 6, 595-602.

[58] Junaid, S.A., Olauboin, F. and Olabode, A.O. (2010) Mycotic Contamination of 
Stock Fish Sold in Jos, Nigeria. Journal of Yeast and Fungal Research, 1, 136-141.

[59] Shahbazian, N., Ebrahimzadeh Mousavi, H.A., Soltani, M., Khosravi, A.R., Mirzargar, S. and Sharifpour, I. (2010) Fungal Contamination in Rainbow Trout Eggs in Kermanshah Province Propagations with Emphasis on Saprolegniaceae. Iranian Journal of Fisheries Sciences, 9, 151-160.

[60] Fayioye, O.O., Fagbohun, T.R. and Olubanjo, O.O. (2008) Fungal Infestation and Nutrient Quality of Traditionally Smoke-Dried Freshwater Fish. Turkish Journal of Fisheries and Aquatic Sciences, 8, 7-13.

[61] Olufemi, B.E. (1983) The Aspergilli as Pathogens of Cultured Fishes. In: Munir, J.F. and Roberts, R.J., Eds., Recent Advances of Aquaculture, Springer, US, 193-217.

[62] Crow, G.L., Brock, J.A. and Kaiser, S. (1995) Fusarium solani Fungal Infection of the Lateral Line Canal System in Captive Scalloped Hammerhead Sharks (Sphyra lewini) in Hawaii. Journal of Wildlife Diseases, 31, 562-565. https://doi.org/10.7589/0090-3558-31.4.562

[63] Wolf, J.C. and Smith, S.A. (1999) Systemic Zygomycosis in Farmed Tilapia Fish. Journal of Comparative Pathology, 121, 301-306. https://doi.org/10.1053/jcpa.1999.0323

[64] Hussein, M.M., Hatai, K. and Nomura, T. (2001) Saprolegniasis in Salmonid and Their Eggs in Japan. Journal of Wildlife Diseases, 37, 204-207. https://doi.org/10.7589/0090-3558-37.1.204

[65] Shabana, Y.M. (2002) The Use of the Host Specific Fungus, Alternaria eichhorniae, for Biological Control of Water Hyacinth. The 2nd Conference on Biological Control of Pests in Egypt, International Center of Agriculture, Cairo, 180-212.

[66] Ali-Shtayeh, M.S., Khaleel, T.Kh.M. and Jamous, R.M. (2002) Ecology of Dermatophytes and Other Keratinophylic Fungi in Swimming Pools and Polluted and Unpolluted Streams. Mycopathologia, 156, 103-205.

[67] Abubakar, M.I. and Tsadu, S.M. (2003) A Survey of Fungal Infestation of Some Commercially Important Fishes in Selected Ponds and Fresh Fish Market in Minna, Niger Sate. Proceedings of the 8th Annual Conference of Animal Science Association of Nigeria, Federal University of Technology, Minna, 15-18 September 2003.

[68] Gamal El-Deen, M.R. and El-Shamery G.R. (2010) Studies on Contamination and Quality of Fresh Fish Meats during Storage. Egyptian Academic Journal of Biological Sciences, 2, 65-74.

[69] Nofiani, R., Kalbar, M. and Ardiningsih, P. (2010) Chemical Characteristic and Microbiological Safety of Commercial Fermented Ale-Ale from West Kalimantan, Indonesia. Journal of Fisheries and Aquatic Science, 5, 483-493. https://doi.org/10.3923/jfas.2010.483.493

[70] Salem-Bekhe, M.M., Abd Al-Azeem, M.W. and Hashim, E.S.Y. (2011) Mycological Aspect of Smoked Fish at Retail Outlet at the Delta Province of Egypt. Journal of Applied Environmental and Biological Sciences, 1, 26-31.

[71] Iqbal, Z., Sheikh, U. and Mughal, R. (2012) Fungal Infections in Some Economically Important Freshwater Fishes. Pakistan Veterinary Journal, 32, 422-426.

[72] Iqbal, Z. and Saleemi, S. (2013) Isolation of Pathogenic Fungi from a Freshwater Commercial Fish, Catla catla (Hamliton). Science International (Lahore), 25, 851855.

[73] Fafioye, O. and Fafioye, O. (2013) Microbial Identification of Smoke-Dried Fish (Clarias gariepinus) from Some Local Markets in Ibadan Metropolis. Wudpecker Journal of Agricultural Research, 2, 294-298.

[74] Rebecca I.E., Ayibawanaimi, O.L. and Chibueze, I.S. (2015) Assessment of Microbi- 
al Quality of Smoked Trachurus trachurus Sold in Some Markets of Three South-South States, Nigeria. International Journal of Food Microbiology, 2, 16-23.

[75] Job, M.O., Agina, S.E. and Dapiya, H.S. (2016) Occurrence of Aflatoxigenic Fungi in Smoke-Dried Fish Sold in Jos Metropolis. British Microbiology Research Journal, 11, 1-7. https://doi.org/10.9734/BMRJ/2016/21465

[76] Galvano, F., Ritieni, A., Piva, G. and Pietri, A. (2005) Mycotoxin in the Human Food Chain. In: Diaz, D., Ed., The Mycotoxin Blue Book, Nottingham University Press, UK, 187-224.

[77] Lass-Florl, C., Rief, A., Speth, C., Leitner, S., Wurzner, R. and Dierich, M.P. (2005) In Vitro Activities of Amphotericin $\mathrm{B}$ and Voriconazole against Aleurioconidia from Aspergillus terreus. Antimicrobial Agents and Chemotherapy, 49, 2539-2540. https://doi.org/10.1128/AAC.49.6.2539-2540.2005

[78] Steinbach, W.J., Perfect, J.R., Schell, W.A., Walsh, J. and Benjamin, D.K. (2004) In Vitro Analyses, Animal Models, and 60 Clinical Cases of Invasive Aspergillus terreus Infection. Antimicrobial Agents and Chemotherapy, 48, 3217-3225. https://doi.org/10.1128/AAC.48.9.3217-3225.2004

[79] Gibbs, S.G., Green, C.F., Tarwater, P.M., Mota, L.C. Mena, K.D. and Scarpino, P.V. (2006) Isolation of Antibiotic-Resistant Bacteria from the Air Plume Downwind of a Swine Confined or Concentrated Animal Feeding Operation. Environmental Health Perspectives, 114, 1032-1037. https://doi.org/10.1289/ehp.8910

[80] Smith, S., Ganiyu, O., John, R., Fowora, M., Akinsinde, K. and Odeigah, P. (2012) Antimicrobial Resistance and Molecular Typing of Pseudomonas aeruginosa Isolated from Surgical Wounds in Lagos, Nigeria. Acta Medica Iranica, 50, 433-438.

[81] Overdevest, I., Willemsen, I., Rijnsburger, M., Eustace, A., Xu, L., Hawkey, P., Heck, M., Savelkoul, P., Vandenbroucke-Grauls, C., van der Zwaluw, K., Huijsdens, X. and Kluytmans, J. (2011) Extended Spectrum $\beta$-Lactamase Gene of Escherichia coli in Chicken Meat and Humans, The Netherlands. Emerging Infectious Diseases, 17, 1216-12122. https://doi.org/10.3201/eid1707.110209

[82] Albuquerque, W.F., Macrae, A., Sousa, O.V., Vieira, G.H.F. and Vieira, R.H.S.F. (2007) Multiple Drug Resistant Staphylococcus aureus Strains Isolated from a Fish Market and From Fish Handlers. Brazilian Journal of Microbiology, 38, 131-134. https://doi.org/10.1590/S1517-83822007000100027

[83] Miranda, C.D. and Zemelman, R. (2001) Antibiotic Resistant Bacteria in Fish from the Concepción Bay, Chile. Marine Pollution Bulletin, 42, 1096-1102. https://doi.org/10.1016/S0025-326X(01)00093-5

[84] Miranda, C.D. and Zemelman, R. (2002) Bacterial Resistance to Oxytetracycline in Chilean Salmon Farming. Aquaculture, 212, 31-47. https://doi.org/10.1016/S0044-8486(02)00124-2

[85] Rodgers, C.J. (2001) Resistance of Yersinia ruckeri to Antimicrobial Agents in Vitro. Aquaculture, 196, 325-345. https://doi.org/10.1016/S0044-8486(01)00546-4

[86] Nataro, J.P. and Kaper, J.B. (1998) Diarrheagenic Escherichia coli. Clinical Microbiology Reviews, 11, 142-201. 
Submit or recommend next manuscript to SCIRP and we will provide best service for you:

Accepting pre-submission inquiries through Email, Facebook, LinkedIn, Twitter, etc. A wide selection of journals (inclusive of 9 subjects, more than 200 journals)

Providing 24-hour high-quality service

User-friendly online submission system

Fair and swift peer-review system

Efficient typesetting and proofreading procedure

Display of the result of downloads and visits, as well as the number of cited articles Maximum dissemination of your research work

Submit your manuscript at: http://papersubmission.scirp.org/

Or contact health@scirp.org 